\section{Pomiędzy zachodnią tradycją epistemologiczną a niesprawiedliwością społeczną. Wokół koncepcji epistemologii Południa Boaventury de Sousy Santosa}

Jadwiga Błahut-Prusik

TEKSTY DRUGIE 2021, NR 3, S. 183-200

DOI: 10.18318/td.2021.3.13 | ORCID: 0000-0003-0741-468X

\section{Wprowadzenie}

„Jesteśmy niewidzialni, niesłyszalni, nieczytelni, ponieważ sukces poprzednich rewolucji nas nie uwzględnił"1. W tym lapidarnym stwierdzeniu Boaventura de Sousa Santos ${ }^{2}$ ujmuje sytuację Globalnego Południa w warunkach globalizacji. Za kluczowe uznaje ignorowanie czy wręcz niedostrzeganie głęboko utrwalonego podziału oddzielającego metropolie od społeczeństw kolonialnych. Upatruje w tym główną przyczynę naszych niepowodzeń w przezwyciężaniu problemów i identyfikowaniu współczesnych zagrożeń. Konflikty w Afryce, kolejne fale imigrantów z Afryki i Azji, niebezpieczne granice południowej Azji to następstwo wielowiekowego wdzierania się Europy na inne kontynenty i zarazem sposób

1 B. Santos Epistemologies of the South: justice against epistemicide, Taylor \& Francis Ltd, London 2014, s. 26.

2 Urodzony w 1940 roku, profesor socjologii na uniwersytecie w Coimbrze (Portugalia). Autor artykułów na temat globalizacji, socjologii prawa i państwa, epistemologii, demokracji i praw człowieka.
Jadwiga Błahut-

-Prusik - dr, adiunkt w Instytucie Filozofii

Uniwersytetu

Warmińsko-

Mazurskiego

w Olsztynie. Autorka monografii Spór

o perspektywy

cywilizacji

zachodniej.Szkice

z amerykańskiej

filozofii społecznej

(2010). Ostatnie

publikacje: ,Inny"jako

wytwór imaginacyjnej

geografii

a globalizacja

(2019), Pomiędzy

bezpieczeństwem,

sekurytyzacja

a językiem (2018). 
utrwalania nierówności. To także szczególne dziedzictwo, które z jednej strony przywołuje kolonialną przeszłość, z drugiej zaś nadal stanowi punkt odniesienia w budowaniu teraźniejszości ${ }^{3}$. W tym kontekście niemożliwe okazują się zrozumienie współczesnych problemów i skuteczna walka z nimi, bez naświetlenia historii widzianej z perspektywy postkolonialnej ${ }^{4}$.

Zaistniały podział i nierówności będące jego konsekwencją Santos charakteryzuje, posługując się metaforą linii otchłani, ilustrującej rozbicie rzeczywistości na dwie części - świat po jednej i świat „po drugiej stronie linii”. Linii przebiegającej między centrum a peryferiami nadaje charakter epistemiczny, ale konsekwencje jej istnienia sięgają dużo dalej - obejmują szeroko ujętą sferę społeczną, w następstwie czego mnoży ona liczne swe odmiany. Rozłam będący jej efektem okazuje się tak głęboki, że wszystko, co znajduje się po jej „drugiej stronie” (rozumianej jako Globalne Południe, Trzeci Świat), pozostaje niewidoczne, wchłonięte przez centrum (Globalną Północ), a co za tym idzie - zupełnie nieistotne. Stąd też podziały, funkcjonujące we wszystkich obszarach ludzkiego życia, Santos metaforycznie nazywa „liniami otchłani" . Są one efektem tego, co Edward Said określał mianem „imaginacyjnych geografii" ${ }^{\prime \prime}$ kulturowych reprezentacji przestrzeni, które nigdy nie pozostają neutralne czy niewinne. Przeciwnie, nadają one realny kształt, treść i kierunek naszym działaniom. Każda forma dominacji wyrastała na gruncie tego rodzaju wyobrażeń, które jako utrwalone sposoby myślenia pozostają najtrudniejsze do przekroczenia ${ }^{7}$.

Źródła istniejących podziałów Santos doszukuje się w sferze epistemicznej. Wychodząc z tego założenia, przekonuje, że zatarcie linii otchłani możliwe jest dzięki epistemologicznej transformacji. Jednak konsekwencją zmiany o charakterze epistemicznym mają być zmiany społeczne. Wszak cała społeczna (polityczna, ekonomiczna i kulturowa) nadbudowa, regulująca nasze działania w tychże obszarach, ugruntowana jest na zachodnim paradygmacie epistemologicznym, co oznacza, że problemów zrodzonych przez linie

3 Por. N. Macqueen Colonialism, Routledge, London-New York 2014.

4 Szerzej zob. S. Krishna Globalization and postcolonialism, hegemony and resistance in the twenty-first century, Rowman \& Littlefield, USA 2009, s. 142-149.

5 B. Santos Epistemologies of the South, s. 26, 106.

6 Por. E. Said Orientalizm, przeł. W. Kalinowski, PIW, Warszawa 1991.

7 E. Said Kultura i imperializm, przeł. M. Wyrwas-Wiśniewska, Wydawnictwo U), Kraków 2009, s. XXIV. 
otchłani nie sposób rozwiązać w odwołaniu do współczesnych terminów, gdyż nauki społeczne, jakie znamy, będąc integralnym komponentem projektu zachodniej nowoczesności, są raczej częścią problemu niż poszukiwanego rozwiązania. W rzeczywistości potwierdzają i umacniają one istniejące podziały. Z tego powodu przejście paradygmatyczne Santos rozumie dwojako: w kategoriach epistemologicznych oraz w kategoriach społecznych. Chodzi więc z jednej strony o nową epistemologię i nową politykę, z drugiej zaś o nową relację między nimi. Aby sprostać temu zadaniu, Santos proponuje budowę projektu emancypacyjnego wolnego od idei postępu oraz uniwersalizmu, jego fundamentem czyniąc epistemologię Południa. Celem artykułu jest pokazanie epistemologii Południa jako alternatywnej narracji nie tylko o znaczeniu poznawczym, ale przede wszystkim społecznym, przybliżenie politycznego kontekstu i znaczenia wiedzy, ukazanie negatywnych doświadczeń (uleganie przemocy, uciskowi, wykluczeniu, dominacji) jako przesłanki do budowania świata i uzasadniania praktyk politycznych alternatywnych w stosunku do zachodnich wzorców.

\section{Epistemologia Południa przeciw epistemologii Północy}

W ciągu ostatnich kilku dziesięcioleci paradygmat zachodniej epistemologii coraz częściej stawał się przedmiotem krytyki, prób jego przekształcania, świadomego odrzucenia, a także wykazania, że konsekwencje założeń epistemologicznych sięgają dużo dalej, poza zakreślony przez nie obszar samego poznania. Więcej, jak wskazuje José-Manuel Berreto, epistemologia staje się dziś jedną z kluczowych dziedzin krytyki nowoczesności i europocentrycznej stronniczości wiedzy oraz walki o sprawiedliwość społeczną. Ów nowy cel wiąże się z rosnącym przekonaniem, że u źródeł niesprawiedliwości politycznej, ekonomicznej i kulturowej leży niesprawiedliwość poznawcza, będąca podstawą wytwarzania wiedzy od początku nowoczesnej kolonizacji. Jak się okazuje, niesprawiedliwości te są ze sobą ściśle powiązane - ustanawiają się i karmią nawzajem ${ }^{8}$. U podstaw kolonializmu legło przekonanie o wyższości okcydentalnej wiedzy nad wiedzą kolonizowanej ludności, które na zawsze zdeterminowało zachodnie pojmowanie polityki, ekonomii, kultury i ugruntowało przeświadczenie o ich uniwersalistycznym charakterze ${ }^{9}$.W odpowiedzi

8 J.-M. Berreto Epistemologies of the South and human rights: Santos and the quest for global and cognitive justice, "Indiana Journal of Global Legal Studies" 2014 vol. 21, no. 2, S. 395, 397.

9 Por. E. Said Orientalizm. 
na doświadczenie przemocy epistemicznej pojawiają się projekty, które zakorzeniają epistemologię w doświadczeniach Globalnego Południa.Tego rodzaju krytycznymi refleksjami dzieli się m.in. Santos. To głos przeciw przemocy epistemicznej, ubóstwu ideowemu, materialnym skutkom neoliberalnej globalizacji.To również głos „klas podrzędnych”, które wbrew tezie Gayatri Chakravorty Spivak ${ }^{10}$ stają się coraz bardziej słyszalne. Nowa optyka epistemiczna ma na celu radykalną dekolonialną krytykę społecznie utrwalonych dychotomii, wykroczenie poza eurocentryczne utopijne koszmary eksportowane jako globalne, imperialne projekty dla pozostałej części świata.

Santos łączy epistemologię z praktyką. Owo podwójne odniesienie - do epistemologii i do pragmatyzmu - oraz ich związanie z doświadczeniem uciskanych staje się pomostem do krytyki epistemologii Północy. Jego koncept, mimo że związany z badaniami nad praktyką, produkcją wiedzy, wypowiedzi, ich obiegu i walidacji, sytuuje się w opozycji do nowoczesnego projektu epistemologicznego ${ }^{11}$, kieruje się ku perspektywie społecznej, poszukując powiązań między wiedzą, prawdą a polityką. W ten sposób idee w nim ujęte nie tylko tłumaczą rzeczywistość, lecz także stają się narzędziem w walce o sprawiedliwość społeczną. Pogląd Santosa pozostaje zogniskowany na kwestii przemocy epistemicznej - analizę i demaskowanie związków między niesprawiedliwością społeczną a tym, co jest uznawane za wiedzę (normę epistemologiczną); między tym, kto tej normie nadaje prawomocność w obrębie poznania, a tym, jak ten proces wpływa na uzyskiwanie przez normodawcę uprzywilejowanej pozycji epistemicznej, a co za tym idzie również społecznej. Przemoc epistemiczna, jak pisze Enrique Galván-Álvares to:

przemoc wywierana [...] przez wiedzę jest prawdopodobnie jednym z kluczowych elementów każdego procesu dominacji. Nie chodzi tylko o budowanie powiązań gospodarczych opartych na wyzysku czy kontroli systemów polityczno-militarnych, które osiągnęły dominację, lecz także [...] konstruowanie ram epistemicznych legitymizujących i gwarantujących te praktyki dominacji. ${ }^{12}$

10 G.Ch. Spivak Czy podporzq̨dkowani inni moga przemówić?, przeł. E. Majewska, "Krytyka Polityczna" $2011 \mathrm{nr} 24 / 25$, s. 196-239. J.A. Nunes O resgate da epistemologia, w: Epistemologias do Sul, ed. B. Santos, M.M. Paula, Cortez Editora, São Paulo 2010, s. 202-203. 
Ustanawianie dominacji jest zatem silnie związane z doświadczeniem przemocy epistemicznej, która często ma niejawny charakter, mieści się jednak w tym, co określa się mianem przemocy symbolicznej, związanej z narzucaniem przez klasę dominującą w danym społeczeństwie swoich idei. Proces globalizacji nawet w większej mierze niż kolonializm zdaje się potwierdzać tę tezę.

Epistemologia Południa wyraża dążenie ludów postkolonialnych, systematycznie poddawanych uciskowi i dyskryminacji w procesie kolonizacji i ustanawiania kapitalizmu, do odzyskania i uprawomocnienia niegdyś odrzucanych form wiedzy zarówno naukowej, jak i nienaukowej. Santos Południe traktuje z jednej strony jako metaforę ludzkiego cierpienia wywołanego przez kapitalizm i kolonializm na poziomie globalnym, a z drugiej oporu mającego na celu pokonanie lub przynajmniej zminimalizowanie doznanej krzywdy. Jest to zatem Południe antykapitalistyczne, antykolonialne i antyimperialistyczne. Jest to Południe, które istnieje również na Globalnej Północy, w postaci wykluczonych, uciszonych i marginalizowanych populacji: nielegalnych imigrantów, bezrobotnych, mniejszości etnicznych i religijnych oraz ofiar seksizmu, homofobii i rasizmu³ ${ }^{13}$.Tym samym za bezpośrednie kryterium wartości wiedzy Santos obiera doświadczenie ucisku. Ocena wiedzy staje się zależna od tego, w jaki sposób wpływa ona na życie i godność uciskanych. Epistemologia Południa jest głosem zwracającym uwagę na antagonistyczne treści wynikające $\mathrm{z}$ różnorodności form nierówności, ucisku i oporu wobec nich ${ }^{\mathbf{1 4}}$.

Oddziaływanie Północy w procesie kolonizacji było tak głębokie, że zdyskredytowało wszystkie społeczne praktyki zdobywania wiedzy sprzeczne z narzuconym interesem. W rezultacie tego procesu, jak wykazuje Santos, doszło nie tylko do straty epistemologicznej, lecz zarazem pociągnęła ona za sobą krzywdę ontologiczną - gorsza wiedza redukuje jej podmiot do poziomu istoty niższej. Walka z przemocą epistemiczną odbywa się więc na dwóch poziomach jednocześnie - epistemicznym i ontologicznym, gdyż przemoc ontologiczna jest konsekwencją przemocy epistemicznej, jest sankcjonowana przez eurocentryczną epistemologię zarówno w nauce, jak i życiu codziennym. W studiach postkolonialnych skuteczną metodę przezwyciężenia przemocy upatruje się we wzajemnym uczeniu się i dialogu między

13 B. Santos Public sphere and epistemologies of the South " Africa Development/Afrique et Développement" 2012 vol. 37, no. 1, s. 51.

14 J.A. Nunes $O$ resgate da epistemologia, s. 211-212. 
odrębnymi światami epistemicznymi - „multiepistemicznej alfabetyzacji”. Celem dialogu między odmiennymi podejściami epistemicznymi, etycznymi, politycznymi jest przekształcenie idei uniwersalnego świata w pluriversal word. Pluriverse wyraża się w możliwości ukonstytuowania się wielu odrębnych ontologii lub światów, które powstają i utrzymują się nawet podczas interakcji, mimo wzajemnego wykluczania czy mieszania się ze sobą ${ }^{15}$.

Santos interpretuje rzeczywistość społeczną z perspektywy utrwalonego w niej rozłamu, będącego konsekwencją ignorowania, niedostrzegania lub celowego eliminowania tej różnorodności. Dzieli ją na „wszechświat po tej stronie linii" - z uniwersalistycznymi i hegemonicznymi wzorami ustanawiania tego, co wartościowe i rzeczywiste, oraz „wszechświat po drugiej stronie linii" - niewidzialny, nieistotny i niezrozumiały. Po jednej stronie linii sytuują się nauka, filozofia i teologia, po drugiej - te rodzaje wiedzy, które nie przystają do żadnego z zachodnich sposobów poznania i wykraczają poza funkcjonujące w zachodniej epistemologii kategorie prawdy i fałszu: myśl potoczna, świecka, plebejska, to przekonania, opinie, magia, bałwochwalstwo, intuicyjne subiektywne rozumienie, wiedza rdzenna. Ta dychotomia pokrywa się z trwale funkcjonującym podziałem wyrażanym przez takie opozycje, jak my-Inni, Północ-Południe, rozwój-zacofanie, centrum-peryferie, społeczeństwa metropolitalne $v s$. terytoria kolonialne itp. Epistemologia zachodniego świata wyrosła na gruncie kolonialnej dominacji wzmacnianej tym, co Santos określa mianem „abisalnego myślenia”, „myślenia otchłani”, będącego źródłem wspomnianych opozycji. Metafora otchłani pozwala Santosowi wyrazić przekonanie, że zachodnie myślenie tworzy i uprawomocnia wiedzę na wzór przepaści oddzielającej teorie wypracowane na Północy od tych tworzonych na Południu. Rozróżnienie to ustanawia hierarchę przejawiającą się w jednostronnym podziale doświadczeń i aktorów społecznych. Z jednej strony na tych, którzy mają monopol na pewną i uniwersalną wiedzę, przez co są użyteczni, zrozumiali i dostrzegani. Z drugiej - tych, których wiedza, sprowadzana do opinii i mniemań, czyni ich bezużytecznymi, niezrozumiałymi, niebezpiecznymi, a w konsekwencji obiektami wyciszenia i marginalizacji. Globalna dynamika deprecjonowania wiedzy niezachodniej pozostaje aktualna ${ }^{16}$. Aby temu przeciwdziałać, Santos proponuje nową epistemologię,

15 J. Sundberg Decolonizing posthumanist geographies, "Cultural Geographies" 2014 vol. 21, no. 1, s. 34, 38. Termin multiepistemic literacy Sundberg zapożycza od Rauna Kuokkanena.

16 B. Santos Epistemologies of the South, S. 167-170; tenże Para alem do pensamento abissal: das linhas globais a uma ecologia de saberes, w: Epistemologias do Sul, s. 25. 
będącą wyrazem dekonstruktywistycznego podejścia zwróconego przeciw zrodzonym podziałom społecznym. W przeciwieństwie do uniwersalistycznej, imperialistycznej epistemologii Północy epistemologia Południa postuluje dostrzeżenie i akceptację kulturowej różnorodności wiedzy, podważającej hegemoniczny dyskurs nowoczesności, przywracając znaczenie „klasom podrzędnym", w konsekwencji eliminującej źródło wielu konfliktów społecznych.

Epistemologię Południa Santos konstruuje, wykorzystując cztery elementy: socjologię nieobecności, socjologię emergencji, ekologię wiedzy oraz przekład międzykulturowy.

\section{Socjologia nieobecności}

Za podmiot socjologii nieobecności Santos obiera Południe, które w procesie kolonizacji zostało zmarginalizowane i uciszone, w konsekwencji czego stało się nieobecne - nie stanowi w jakimkolwiek stopniu propozycji alternatywnej wobec międzynarodowego reżimu Północy, konstytutywnego dla hegemonicznej globalizacji.Zadaniem socjologii nieobecności jest przywrócenie nieobecnemu podmiotowi jego obecności, znaczenia, co można osiągnąć jedynie dzięki transformacji epistemologicznej. Nieistnienie, w opinii Santosa, jest rezultatem dyskredytacji, braku akceptacji czy przyzwolenia na odmienność, która ma przede wszystkim charakter epistemiczny. Niezdolność poznawcza implikuje nieistnienie, podmiot zostaje uznany za niezrozumiały, a co za tym idzie - zbędny, bezwartościowy, i staje się niewidoczny.

Santos wskazuje na kilka sposobów ustanawiania nieobecności Południa, mających wspólne źródło - „monokulturową racjonalność”, która de facto jest wyrazem oświeceniowego projektu realizowanego na niezachodnich obszarach. Będąca jego efektem globalizacja wywodzi się z praktyk kolonialnych. W tej perspektywie globalizacja może być postrzegana jako współczesna forma zachodniego imperializmu, mająca swe historyczne korzenie w polityce podboju i wytwarzanej dominacji. Jako taka, podobnie jak niegdyś kolonializm, ustanawia rozliczne formy nieistnienia - unicestwia, spycha na margines zarówno jednostki, jak i całe kultury, społeczeństwa, obszary.

Analizowane przez Santosa sposoby ustanawiania nieobecności okazują się konstytutywne dla globalizacji. Każdy z nich tworzy, utrwala i legitymizuje funkcjonujące nierówności. Pierwszy czerpie $\mathrm{z}$ „monokulturowości wiedzy", sprowadza się do uznania współczesnej nauki i kultury wysokiej za podstawowe kryterium prawdy i wartościowania estetycznego. W rezultacie wszystko, co nie jest rozpoznane lub usankcjonowane przez ów kanon, 
zostaje uznane za nieistniejące. Drugi sposób zakorzeniony jest w idei „monokulturowości linearnego czasu". Zgodnie z nią historia ma dobrze znany, określony sens i kierunek, różnorako konkretyzowane przez ostatnie dwieście lat, m.in. jako postęp, rewolucja, modernizacja, rozwój i globalizacja. W tej perspektywie za nieistniejące uznane zostaje to, co wsteczne, zacofane, czyli asymetryczne względem tego, co postępowe. Nieistnienie przybiera tu formę niższości niemożliwej do przezwyciężenia z powodu uznania jej naturalnego charakteru. Nieistnienie to również wytwór „logiki dominującej skali", determinującej nieistotność wszystkich innych możliwych skal. W zachodniej nowoczesności przybiera ona podwójną postać uniwersalizmu i globalności. Uniwersalizm Santos odnosi do skali podmiotów, które dominują niezależnie od konkretnych kontekstów, sytuując się ponad nimi. Z tego powodu mają one pierwszeństwo przed innymi podmiotami, których znaczenie jest od nich zależne. Globalizację z kolei wiąże ze skalą przyznającą przywileje podmiotom oddziałującym na całość globu. Zgodnie z tą logiką nieistnienie pojawia się pod postacią tego, co konkretne i lokalne. Podmioty tak zdefiniowane są niezdolne być wiarygodną przeciwwagą dla tego, co istnieje globalnie i powszechnie. Piąta logika nieistnienia - „logika produktywności" - tkwi w monokulturze kryteriów kapitalistycznej wydajności, w myśl której niekwestionowanym racjonalnym celem działania jest wzrost gospodarczy, a wraz z nim wzrost wydajności. Kryterium wydajności dotyczy zarówno natury (płodność), jak i ludzkiej pracy (produktywność). W tym kontekście nieistnienie przyjmuje postać jej przeciwieństwa. W wypadku natury to bezpłodność, w wypadku pracy - lenistwo lub zawodowa dyskwalifikacja" ${ }^{17}$.

Nieistnienie stanowi skrajną konsekwencję funkcjonujących podziałów społecznych. Taka forma radykalnego zaprzeczenia okazuje się fatalna w skutkach - trwale eliminuje wszelkie realia "po drugiej stronie linii”, czyniąc je niewidocznymi, nieistotnymi, nieistniejącymi, wykluczonymi. Jak zauważa Santos, świat funkcjonujący „po drugiej stronie linii”, wykraczając poza prawdę i fałsz, wykracza również poza legalność i nielegalność; tworzy terytoria sytuujące się poza prawem, a-legalne, gdzie brak wyraźnego podziału na to, co zgodne i niezgodne z prawem. Pozbawienie charakterystycznej dla Zachodu hierarchii czyni obszary postkolonialne terytoriami właściwymi Hobbesowskiemu stanowi natury. Teoretyczny tego wyraz odnajdziemy m.in. w XVII- i XVIII-wiecznych teoriach umowy społecznej i stanu natury, które 
mają znaczenie, zdaniem Santosa, nie tylko ze względu na to, o czym mówią, lecz także to, o czym milczą. Mówią o tym, że ludzie metropolitalni porzucają stan natury, tworząc społeczeństwa obywatelskie. Milczą jednak o tym, że rozległa część świata pozostaje w stanie natury. Więcej, to właśnie koncepcja prawomocnej pustki uzasadniała inwazję i okupację rdzennych terenów ${ }^{\mathbf{1 8}}$, niegdyś za pomocą praktyk kolonialnych, dziś - globalizacji.

Wykluczeniu ludności „po drugiej stronie linii” Santos przypisuje dodatkowe znaczenie - przyjmuje je za warunek samouznania, uniwersalności tego, co po stronie przeciwnej, Globalnej Północy. Według Santosa, tezę tę dawniej potwierdzały praktyki kolonialne, ale pozostaje ona aktualna również dziś. Współczesna zachodnia myśl nadal dzieli świat na ludzki i podludzki. Punktem odniesienia staje się tu globalizacja z jej skutkami. Za przykład najbardziej groteskowej manifestacji „otchłaniowego myślenia" prawnego, tworzenia nie-terytorium w sensie prawnym i politycznym, przestrzeni „nie do pomyślenia” w obszarze rządów prawa, praw człowieka i demokracji, Santos podaje obóz Guantanamo. Tego rodzaju miejsc jest jednak więcej, podobnie jak istnieją miliony "guantanamończyków" - dyskryminowanych seksualnie i rasowo zarówno w sferze publicznej, jak i prywatnej, żyjących na peryferiach megamiast, w gettach, więzieniach, poddawanych nowym formom niewolnictwa (handel ludźmi, praca nieletnich) ${ }^{19}$. Zjawisko to Santos określa mianem „faszyzmu społecznego", wyrażającego się w skrajnie nierównych relacjach władzy. Wiąże go ze zbiorem procesów społecznych, w których duże grupy ludzi są nieodwracalnie trzymane na zewnątrz lub wykluczane z jakiejkolwiek umowy społecznej. W przeciwieństwie do swych historycznych form jest on pluralistyczny, łatwo współistnieje z demokratycznym państwem ${ }^{20}$ i z tego powodu okazuje się jeszcze bardziej niebezpieczny. W tym sensie Santos mówi o reanimacji rządów kolonialnych w społeczeństwach metropolitalnych. Obecnie powrót kolonializmu przybiera postać groźnych wtargnięć społeczeństw kolonialnych do metropolii. Zwrot ten ma trzy główne formy: terroryzm, nielegalną imigrację oraz uchodźstwo. Każda z nich na różne sposoby wyraża piętno globalnej linii otchłani, która konstytuuje radykalne wykluczenie i nieistnienie prawne. Różnica między

B. Santos Para alem, s. 25, 26-29.

19 Tamże, s. 29-30. 
jego tradycyjną a nową postacią wyraża się w mobilności kolonizowanego. Niegdyś nie miał on wstępu do społeczeństwa metropolitalnego inaczej niż z inicjatywy kolonizatora (np. jako niewolnik), obecnie przekracza je na różne sposoby. Tym samym linie przestrzeni metropolitalnych zostają przekroczone, w pewnym sensie się krzyżują. Niegdyś kolonizowany, wchodząc do ucywilizowanego świata, staje się dla niego bezpośrednim zagrożeniem. W celu ochrony powstają ufortyfikowane enklawy (prywatne miasta, strzeżone społeczności), będące formą nowej segregacji miejskiej, nowej hegemonicznej czasoprzestrzeni, która przenika wszystkie relacje ekonomiczne, polityczne i kulturowe ${ }^{21}$. Globalizacja nie znosi peryferyjności Południa, Inny stoi bliżej niż kiedykolwiek, ale wyobrażenie o nim pozostaje zakorzenione w odległej kolonialnej przeszłości. W procesie globalizacji zrodziły się nowe mechanizmy i narzędzia wcielania i kreowania zależności, co potwierdzają nie tylko rozważania Santosa. Jednak w perspektywie żywej zachodniej krytyki globalizacji oczywiste jest to, że podziały zrodzone w procesie globalizacji zachodzą również w samym sercu Północy, nie dotyczą jedynie Południa.

Pozostałe kroki w budowaniu epistemologii Południa ściśle łączą się z socjologią nieobecności, tj. wskazują na metody odzyskiwania przez zmarginalizowany podmiot znaczenia, istnienia.

\section{Socjologia emergencji}

Według Santosa, celem socjologii emergencji jest budowanie przyszłości na podstawie pluralistycznych, konkretnych, utopijnych ${ }^{22}$ i realistycznych projektów realizowanych w teraźniejszości. Istotę tego, co postuluje ten badacz, najtrafniej oddaje koncepcja Ernesta Blocha „Not Yet”.

„Jeszcze nie" jest czymś, co wisi w powietrzu jeszcze nie urzeczywistnione, lecz przecież także nie unicestwione. Kategoria „jeszcze nie” odnosi się do świata, w którym możliwe są realizacje projektów i przemiany

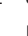
nieustannym przekraczaniem status quo, dążeniem do zmiany, realizacją obranego ideału. "Utopijność jest gwiazdą przewodnią wszelkiego planowania" - pisze. E. Bloch Rzeczywistości antycypowane, czyli jak przebiega i co osiq̨ga myślenie utopijne, przeł. A. Czajka, „Studia Filozoficzne" $1982 \mathrm{nr} 7 / 8, \mathrm{~s} .54$. 
świata, który sam jest jeszcze otwarty, niegotowy, procesualny, a przez to fragmentaryczny, jednym słowem, do świata, którego horyzont stale się poszerza. ${ }^{23}$

W nawiązaniu do koncepcji „Not Yet” Santos proponuje stworzenie warunków dla alternatywnych rozwiązań społecznych, które dalece wykraczałyby poza istniejące, często narzucane uwarunkowania czy obrany kierunek zmian. Poszukując nowej drogi, przedstawia projekt, który w nawiązaniu do eseju filozoficzno-politycznego José Martíego Nuestra América określa tym samym terminem. „Nuestra América” rozumie jako formę podmiotowości i kooperacji, sposób życia w nieustannym przemijaniu, przekraczaniu granic, tworzeniu pogranicza, otwarcie na ryzyko ${ }^{24}$. Tego rodzaju podmiotowość i współdziałanie najlepiej realizują się w obszarze myślenia utopijnego, tj. przez eksplorację nowych sposobów ludzkich możliwości i chęci, przez wyobrażenie sobie lepszej przyszłości, o którą warto walczyć i do której każdy ma prawo. Zadaniem socjologii emergencji jest badanie pojawiających się możliwości ${ }^{25}$.

Zdaniem Santosa, „Nuestra América” może posłużyć jako symbol utopijnej woli emancypacji i poddania procesów globalizacyjnych kontrhegemonizacji. Uznaje to za możliwe pod warunkiem przekształcenia jej w metaforę walki ofiar hegemonicznej globalizacji. Sprzyja temu kilka czynników. Po pierwsze, gwałtowny wzrost interakcji transgranicznych. Zwiększająca się liczba emigrantów, studentów, uchodźców, kadry zarządzającej, turystów daje początek nowym formom transkulturacji na całym świecie. Po drugie, odrodzenie rasizmu zarówno na Globalnej Północy, jak i Południu, będące wyrazem obrony przed małymi grupami powstającymi w rezultacie krzyżowania się i przenikania. Po trzecie, sprzeciw wobec ignorancji i efektu wyciszenia, jaki wytwarza współczesna nauka wykorzystywana przez hegemoniczną

Tamże, s. 53.

Na co narażone jest Globalne Południe? Zdaniem Santosa, na ryzyko śmierci z innych powodów niż choroba; na bycie rannym lub zabitym; na utratę ziemi, wody, domu, świętych miejsc, dzieci, dziadków; na odległe przesiedlenia (w ucieczce przed wojną lub przed zamkniętymi dzielnicami miast); na zanieczyszczenia lokalnych rzek i wylesienia lasów w imię tego, co Globalna Północ zwykła nazywać rozwojem. Południe jest narażone na poniżenie bez możliwości reagowania, gdyż jego ludność uznawana jest za gorszą pod względem płci, rasy, klasy, kasty; grożą mu działania możnych, które mogą się okazać dla niej [niego] śmiertelne. Zob. B. Santos Epistemologies of the South, s. 26.

Tamże, s. 87. Szerzej zob. tegoż Public sphere, s. 54-56. 
globalizację. Po czwarte, globalna bliskość, będąca rezultatem rozwoju informacyjnego i komunikacyjnego, tworzy grunt nie tylko dla ich krytyki, lecz także dla postkolonialnego impulsu - sprzyja powstawaniu sojuszy emancypacyjnych. Według Santosa, antyhegemoniczna natura „Nuestra América" tkwi w jej potencjale do rozwoju ponadnarodowej kultury politycznej, skoncentrowanej na identyfikacji licznych lokalnych i globalnych powiązań między walkami, ruchami i inicjatywami społecznymi, na sprzeciwie wobec globalnych hegemonicznych trendów przez promowanie transnarodowych koalicji ${ }^{26}$. Możliwości, jakie dostrzega Santos w socjologii emergencji, poszukującej nowej formy zaznaczenia obecności zmarginalizowanego podmiotu, ujawniają swego rodzaju paradoks. Okazuje się, że socjologia emergencji jako remedium na zakorzenione w kolonialnym dziedzictwie skutki globalizacji może urzeczywistnić się dzięki warunkom tego samego globalnego świata, który stara się krytykować i zmienić. To jeden z wielu dowodów na wysoce ambiwalentny charakter globalizacji, na inkluzywność i jednoczesne wykluczenie, jakie generuje.

\section{Ekologia wiedzy}

Ekologia wiedzy bazuje na przeświadczeniu o jej kontekstualności. Nie istnieje wiedza poza praktyką społeczną. Jak ujmuje to João Arriscado Nunes, konkludując myśl Santosa: „wiedzę możemy zrozumieć i oceniać tylko wtedy, gdy podchodzimy do niej jako do praktyki"27. Relacje społeczne są zawsze kulturowe i polityczne, stąd też każda wiedza rodzi się pod wpływem określonych kontekstów. Ich ignorowanie, celowe eliminowanie z refleksji nad kulturowymi i politycznymi warunkami produkcji i reprodukcji wiedzy to, zdaniem Santosa, zasadniczy błąd epistemologii ostatnich dwóch stuleci i główna przyczyna utrwalanych nierówności. W ciągu minionych dwustu lat relacja między wiedzą a działaniem społecznym została zredukowana do związku między wiedzą potwierdzoną przez współczesną naukę a racjonalną inżynierią społeczną. W rezultacie wszystko, co arbitralnie przyjęto jako znajdujące się poza racjonalizowanym polem, zostało zignorowane lub napiętnowane. Na zewnątrz pozostał mroczny świat namiętności, intuicji, uczuć, emocji, przekonań, wyznań, wartości, mitów - uznany za nieistotny

B. Santos Epistemologies of the South, s. 100-102.

27 J.A. Nunes O resgate da epistemologia, s. 217. 
lub niebezpieczny. To rozdzielenie teorii i praktyki, twierdzi Santos, sprawiło, że obie stały się jałowe ${ }^{28}$.

Południowa krytyka dekolonialna zasadza się nie tylko na przekonaniu o kontekstualności wiedzy i jej ostatecznej fragmentaryczności, ale przede wszystkim kwestionuje jej uniwersalny charakter. Przeświadczenie o uniwersalności epistemologii Północy stało się możliwe wskutek ukrycia podmiotu, który mówi, tj. tworzy, przekazuje, narzuca wiedzę. Jak ujmuje to Ramón Grosfoguel, w zachodniej filozofii i nauce podmiot, który mówi, jest niewidoczny, wymazany z analizy. Egocentryczna polityka kreowania wiedzy uprzywilejowywała mit nieusytuowanego „ego". Położenie etniczne, rasowe, płeć i lokalizacja epistemiczna zostały od siebie oddzielone. Na podstawie tej separacji zachodnia filozofia i nauka stworzyły mit o uniwersalistycznej wiedzy, ukrywając zarówno tego, kto mówi, jak i jego geopolityczne położenie w strukturach władzy. Zrodzony „boski punkt widzenia”, skrywający swoją lokalną i partykularną perspektywę za abstrakcyjnym uniwersalizmem, pozwolił człowiekowi Zachodu przedstawiać swoją wiedzę jako jedyną zdolną zaistnieć w powszechnej świadomości, a wiedzę niezachodnią uznać za marginalną. Ta strategia okazała się kluczowa dla zachodnich projektów globalnych. Ukrywając lokalizację wypowiadającego się podmiotu, kolonialna europejska/euroamerykańska ekspansja i dominacja były w stanie skonstruować hierarchię wyższej i niższej wiedzy, a tym samym - nadrzędnych i podrzędnych, lepszych i gorszych ludzi, świata ludzi i podludzi ${ }^{29}$.

Studia postkolonialne uwrażliwiają na kwestie przestrzenności i znaczenia miejsca w tworzeniu wiedzy. „Brak refleksji na temat geopolityki i przestrzenności w produkcji wiedzy idzie w parze z brakiem refleksji nad zaangażowaniem zachodniej filozofii i filozofów w Europie jako epistemicznie uprzywilejowanym miejscu"30 - zauważa Nelson Maldonado-Torres. Według niego, przestrzenność jako istotny czynnik w zrozumieniu filozofii i produkcji teorii społecznej może stworzyć nową ideę odległego obserwatora, zdolnego badać zawiłe relacje między wiedzą a przestrzenią tylko dlatego, że sytuuje się poza tymi relacjami. Nie chodzi jednak o wiarę w bezstronność, która ostatecznie ma tendencję do odtwarzania ślepoty, ale o pozaeuropejskie sposoby

B. Santos Epistemologies of the South, s. 22; tenże Para alem, s. 13.

R. Grosfoguel World-systems analysis in the context of transmodernity, border thinking, and global coloniality, "Review (Fernand Braudel Center)” 2006 vol. 29, no. 2, s. 168-169.

30 N. Maldonado-Torres A topologia do ser e a geopolítica do conhecimento. Modernidade, império e colonialidade, w: Epistemologias do Sul, s. 307. 
myślenia. Koncepcja nowoczesności polegała na ukryciu tego, jakie znaczenie ma przestrzeń w produkcji dyskursu nowoczesności, przyjmując perspektywę uniwersalistyczną, eliminującą znaczenie położenia geopolitycznego ${ }^{31}$. Milczenie na temat usytuowania wiedzy odtwarza teorię eurocentryczną jako uniwersalny, jedyny istotny zasób wiedzy. Należy jednak zaznaczyć, że w XIX- i XX-wiecznej filozofii europejskiej i naukach społecznych ukształtowały się nurty usiłujące uprawomocnić rolę podmiotu ${ }^{32}$ i związanych z nim indywidualnych doświadczeń. Mimo że można zarzucić myślicielom Południa, iż generalizują i upraszczają tę kwestię, uznając podmiot za całkowicie wyparty, nie ulega wątpliwości, że w całym okresie podbojów kolonialnych takowym pozostawał.

Główną przesłankę ekologii wiedzy stanowi przekonanie, że niesprawiedliwość społeczna jest głęboko zakorzeniona w niesprawiedliwości poznawczej, gdyż określone interpretacje świata zawsze faworyzują grupy społeczne mające do nich dostęp. Nowoczesne społeczeństwo kapitalistyczne proteguje praktyki, w których przeważa wiedza naukowa. Oznacza to, że naukowe interpretacje rzeczywistości zyskują uprzywilejowany status. Tymczasem, zdaniem Santosa, jeśli walka o sprawiedliwość poznawczą ma być skuteczna, nie może być ograniczona wyłącznie do idei bardziej zrównoważonej dystrybucji wiedzy naukowej. Z tego powodu ekologia wiedzy bazuje na przeświadczeniu, że epistemologia powinna uznawać heterogeniczność wiedzy oraz trwałość i dynamikę interakcji między odmiennymi jej postaciami, bez uszczerbku dla ich autonomii. Wyjście poza wiedzę naukową oznacza odrzucenie uniwersalnej epistemologii, odejście od jakiejkolwiek stałej hierarchii wiedzy. Ekologia wiedzy pojawia się w rezultacie wzrastającej świadomości nowych podmiotów, w oporze przeciw hegemonicznej globalizacji, globalnemu kapitalizmowi. Ze względu na postulowaną różnorodność nie tworzy jednorodnej propozycji alternatywnej wobec epistemologii Północy, dąży do nadania epistemologicznej spójności myśleniu pluralistycznemu, gdyż osadzona jest zarówno w zachodnich, jak i niezachodnich kulturach, różnych językach, odmiennych kategoriach oraz sprzecznych projektach tzw. dobrego życia. Nie dyskredytuje ona także wiedzy naukowej, sprzeciwia się jedynie jej hegemonicznemu charakterowi. Zasada niepełnego charakteru wszystkich rodzajów wiedzy warunkuje możliwość prowadzenia epistemologicznego

Tamże, s. 308, 319 .

32 Jako przykład posłużyć mogą egzystencjalizm, fenomenologia, pragmatyzm. 
dialogu i debaty między nimi3 ${ }^{33}$. Wziąwszy pod uwagę konsekwencje społeczne funkcjonującego paradygmatu epistemologicznego, wydaje się, że warunkuje również dialog i debatę w każdym innym obszarze. Zakorzeniając niesprawiedliwość społeczną w niesprawiedliwości poznawczej, Santos zwraca uwagę na holistyczny wymiar rzeczywistości, w której funkcjonujemy. Potwierdza jednocześnie konieczność całościowego podejścia przy próbach analizy i rozwiązywania problemów, przed jakimi stoimy.

\section{Przekład międzykulturowy}

Z postulatu dialogu między różnymi rodzajami wiedzy wypływa czwarta idea epistemologii Południa - przekład międzykulturowy. Santos prezentuje orientację metodologiczną opartą na idei niekompletności wszystkich kultur. Toposy danej kultury stanowią główne przesłanki rozumowania w obrębie danej kultury, umożliwiają tworzenie i wymianę argumentacji, ale tworzą jedynie iluzję epistemicznej kompletności i samowystarczalności. Zdaniem Santosa, niekompletność danej kultury można ocenić tylko w odwołaniu do innej.

Praca nad przekładem dotyczy zarówno odmiennych rodzajów wiedzy, jak i związanych z nimi praktyk. Przybiera ona formę "diatopicznej hermeneutyki", która - jak twierdzi Santos - sprawia, że ekologia wiedzy staje się możliwa. Jej celem jest zwiększenie świadomości wzajemnej niekompletności kultur poprzez angażowanie się w dialog - jakby się było jedną nogą w jednej, a drugą w innej kulturze. „Diatopiczna hermeneutyka” dąży do przekształcania przesłanek, argumentacji zrozumiałych jedynie w jednej kulturze w wytłumaczalne, wiarygodne argumenty w innej. Jest to, zdaniem Santosa, trudna procedura postkolonialna, postimperialna, a w pewnym stopniu nawet posttożsamościowa. Źródłem energii napędzającej „diatopiczną hermeneutykę" jest to, co określa on mianem „epistemicznego morderstwa wiedzy”. Nierówna relacja między kulturami zawsze implikuje śmierć wiedzy kultury podporządkowanej, a co za tym idzie, marginalizację grup społecznych ją tworzących ${ }^{34}$. Zadanie, jakie Santos wyznacza „diatopicznej hermeneutyce", wydaje się decydujące o sukcesie wysiłków zmierzających do usunięcia nierówności, gdyż w procesie globalizacji to właśnie bezprecedensowy zasięg

Szerzej zob.: B. Santos Epistemologies of the South, s. 38-40; tegoż Public sphere, s. 57-58. 
autorytetu kulturowego okazuje się kluczowy w ustanawianiu dominacji i wykluczania.

Epistemologię Południa Santos traktuje jako swego rodzaju siatkę bezpieczeństwa przed otchłanią, w którą spadamy, gdy tracimy pewność, że wiedza naukowa jest jedynym ważnym rodzajem wiedzy, a poza nią istnieje jedynie niewiedza. Uznaje ją za najskuteczniejsze antidotum na Wittgensteinowskie milczenie. „Czego nie da się powiedzieć jasno w jednym języku lub kulturze, można powiedzieć jasno w innym języku lub kulturze"35 - konkluduje. Uznanie innych rodzajów wiedzy w dyskusji otwiera pole do nieograniczonej dyskursywnej i pozadyskursywnej wymiany między kulturami wzajemnie nieznanych dotąd kodów symbolicznych.

\section{Podsumowanie}

Obecność globalnych linii otchłani Santos uznaje za stałą, za zmienną zaś jedynie ich formę. Traktuje kolonializm jako metaforę określającą doświadczenia życia „po drugiej stronie linii”, utrwalane w procesie globalizacji. Bliski kontakt między Południem a Północą nie usuwa ich nie tylko z tego powodu, że tkwią głęboko w świadomości, przeciwnie, wzmacnia je, ukazując paradoksalne skutki tego spotkania i żywotność kolonialnego dziedzictwa. Santos obala jeden z najpotężniejszych mitów XX wieku - tezę o dekolonizacji współczesnego świata. Nadal żyjemy w kolonialnych strukturach, z tą różnicą, że „wraz z polityczno-prawną dekolonizacją przenieśliśmy się z okresu «globalnego kolonializmu» do obecnego okresu «globalnej kolonialności»" ${ }^{\text {, }}$ która, jak się okazuje, nie jest „przeszłością” nowoczesności, lecz jej „druga twarzą". Wciąż odwołuje się do różnic w sile i wiedzy, do technologii władzy. Logika zawłaszczania i przemocy wyraża się obecnie we współistnieniu faszyzmu społecznego z demokracją liberalną, stanu wyjątkowego z regułami konstytucyjnymi, rządów prawa z miękkim prawem. Bez świadomości i przełamania tych paradoksów nie zdołamy sprostać wyzwaniom, jakie niesie ze sobą globalizacja.

Tamże, s. 36.

36 R. Grosfoguel World-systems analysis, s. 175. Za Quijano przez sytuacje kolonialne Grosfoguel rozumie kulturowy, polityczny, dotyczący płci, duchowy, epistemiczny i ekonomiczny ucisk/ wyzysk podległych grup rasowych/etnicznych przez grupy dominujące bez istnienia administracji kolonialnych. Tamże, s. 175-176. 
Epistemologia Południa stanowi cenny wkład w analizę współczesnych procesów ekonomicznych, politycznych i kulturowych, a co za tym idzie, w poszukiwanie rozwiązań problemów występujących w tych obszarach. Ukazuje źródło słabości uniwersalnych struktur, jakie Północ narzuciła reszcie świata, która wszak pozostaje głęboko pluralistyczna. Współczesne kryzysy, wciąż nowe ich oblicza i skutki, załamywanie się struktur politycznych, gospodarczych, zdają się potwierdzać intuicje Santosa. Wskazując na epistemologiczne źródło licznych problemów, Santos dowodzi, że mają one dużo głębsze przyczyny, a ich rozwiązanie nie będzie możliwe bez holistycznego podejścia.

Epistemologia Południa pozwala dostrzec wcześniej rzadko artykułowane skutki dominacji zachodniego paradygmatu epistemologicznego. Daje możliwość oglądu funkcjonujących głębokich podziałów z innej niż zachodnia perspektywy. I mimo że obecnie trudno wyobrazić sobie jakiekolwiek rozwiązanie alternatywne wobec istniejącego reżimu międzynarodowego, który stał się podstawowym elementem hegemonicznej globalizacji, a postulaty wysuwane przez Santosa z zachodniego punktu widzenia wydają się utopijne (nie w znaczeniu, jakie utopii przypisuje Santos), nie sposób zaprzeczyć, że jest to konieczne i pilne. Obecny system traci spójność, staje się coraz bardziej wywrotowy i nieprzewidywalny, zwiększając tym samym wrażliwość podległych klas, grup społecznych, regionów i narodów. W tej perspektywie epistemologia Południa niesie wartościowe przesłanie społeczne, polityczne i kulturowe. 


\section{Abstract}

\section{Jadwiga Błahut-Prusik}

UNIVERSITY OF WARMIA AND MAZURYIN OLSZTYN

Between the Western Epistemological Tradition and Social Injustice: On Boaventura de Sousa Santos' Epistemologies of the South

Błahut-Prusik outlines epistemologies of the South, a narrative that presents an alternative to Western models. This narrative has a cognitive as well as social dimension, as Błahut-Prusik shows by pointing to its political context and the meaning of knowledge; she also highlights negative experiences (being subjected to violence, oppression, exclusion and domination) as being consequences of an alternative view of the world and justification of political practices. Błahut-Prusik analyses the relationship between the Western epistemological tradition with social injustice as well as the consequences of this relationship - the profound divisions that are rooted in colonial practices but continue to operate until this day. Sousa Santos' book Epistemologies of the South presents a framework for these reflections, shedding a new light on social problems that we face today; it seeks to identify their sources in the Western epistemological tradition.

\section{Keywords}

colonialism, epistemology of the South, Boaventura de Sousa Santos, epistemic violence, globalisation 